\title{
Surgeon-specific factors affecting treatment decisions among Canadian urologists in the management of pTla renal tumours
}

\author{
Alexandra Leora Millman, MD; Kenneth T. Pace, MD, FRCSC; Michael Ordon, MD, FRCSC; \\ Jason Young Lee, MD, FRCSC
}

Division of Urology, Department of Surgery, St. Michael's Hospital, University of Toronto, Toronto, ON

Cite as: Can Urol Assoc J 2014;8(5-6):183-9. http://dx.doi.org/10.5489/cuaj.1884

Published online June 16, 2014.

\section{Abstract}

Introduction: The ubiquitous use of diagnostic imaging has resulted in an increased incidental detection of small renal masses (SRM). Patient- and tumour-related factors affect treatment decisions greatly; however, with multiple treatment options available, surgeonspecific characteristics and biases may also influence treatment recommendations. We determine the impact of surgeon-specific factors on treatment decisions in the management of SRM in Canada.

Methods: An online survey study was conducted among Canadian urologists currently registered with the Canadian Urological Association. The questionnaire collected demographic information and recommended treatments for 6 SRM index cases involving theoretical patients of various ages (51-80 years) and comorbidities. Results: A total of 110 urologists responded ( $17 \%$ response rate) to the survey. Of these, $18 \%$ were over 65 years old and $45 \%$ were from academic centres. With increasing patient age and comorbidity, active surveillance and thermal ablative therapies were more the recommended treatment. Laparoscopic/robotic surgery was more commonly recommended by academic urologists and those under 65. Recommending surgery (radical nephrectomy or partial nephrectomy) for both elderly (about 80 years old) index patients correlated with surgeon age (surgeons over 65, $p<0.001$ ), surgeons with no oncologic fellowship training $(p=0.021)$, surgeons with a non-academic practice $(p=0.003)$, surgeons with a personal history of cancer $(p=0.038)$ and surgeons with a family history of cancer death in the last 10 years $(p=0.022)$. Conclusions: There are various factors that influence the management options offered to patients with SRMs. Our results suggest that surgeon age, personal history of cancer, practice-type and other surgeon-specific variables may affect treatments offered among urologists across Canada.

\section{Introduction}

The ubiquitous use of diagnostic imaging has resulted in an increased incidental detection of small renal masses (SRM). ${ }^{1}$ Although not every SRM requires treatment, about $75 \%$ are malignant. ${ }^{2-4}$

Nephron-sparing surgery (NSS) has gained popularity over the last 2 decades, ${ }^{5}$ given the long-term morbidity and mortality associated with chronic renal insufficiency. ${ }^{6}$ Furthermore, partial nephrectomy (PN) has been shown to have excellent oncologic outcomes in the treatment of pT1a renal cell carcinomas (RCC). ${ }^{7-10}$ Utilization rates, however, have remained low for a variety of reasons. ${ }^{11-13}$

Cryoablation, radiofrequency ablation (RFA) and active surveillance (AS) have become recognized, viable, nephronsparing treatment options for clinical T1a RCC, especially in elderly patients and those with a higher surgical risk. ${ }^{13-15}$

While there are several evidence-based guidelines regarding the management of T1a RCC, many factors affect the ultimate treatment decision. To further aid clinicians with this often complex decision, scoring rubrics, such as the R.E.N.A.L. nephrometry and PADUA scores, have been developed to help predict the risk of surgical complications and postoperative renal function. ${ }^{16-22}$

Despite these guidelines and scoring systems, a lack of consensus often exists among urologists when different treatment options are presented for the same patient. While much of the discussion may focus around patient and diseasespecific factors, a variety of surgeon-specific factors may also influence treatment decisions.

Gaining a better understanding of the surgeon-specific factors that can affect treatment decisions in RCC in Canada will provide more insight into the current clinical paradigm and may improve patient care moving forward. As such, we conducted an online survey of Canadian urologists to assess these surgeon-specific factors. 
Millman et al.

\section{Methods}

\section{Recruitment}

Between March and May 2013, 3 e-mail blasts were sent to Canadian Urological Association (CUA) members, inviting them to participate in an online survey regarding the treatment of SRMs. All responses were de-identified and collected on the secure Survey Monkey website server. IP addresses were used to exclude repeat responses.

\section{Survey}

The survey consisted of two sections; the first involved the collection of respondent demographic information and the second included six index RCC cases (C1 to C6) of various ages and comorbidities (Table 1). All 6 cases involved patients with incidentally detected, biopsy confirmed, RCC measuring roughly $3 \mathrm{~cm}$, with nephrometry score 4 a. The patient's estimated GFR was also provided for each index case (Table 1).

For each case, respondents were asked to select, from a standardized list, their recommended management choice. Participants were also asked to select and rank 3 variables that most influenced their treatment decision (Table 2).

\section{Statistical methods}

Data was analyzed using SPSS software v. 21. Demographic and clinical practice details were correlated to recommended treatment options. Data were analyzed using Pearson and Spearman correlation for continuous and categorical data, respectively. McNemar's test was used to compare proportions between dependent groups and multivariable regression analysis was conducted to estimate any relationship between various factors.

\section{Results}

The e-mail blast was sent to 632 CUA members, with a $17 \%$ response rate $(n=110)$. The authors were personally contacted by 24 CUA members indicating that they were either retired or pediatric urologists, giving an adjusted response rate of $18 \%(110 / 608)$.

\section{Demographics}

Of the respondents, 90\% $(n=99)$ were male and most had completed residency training in Canada (93\%). Almost half $(45 \%)$ were practicing in an academic setting and $18 \%$ were over 65 . Most (63\%) participants reported seeing RCC

\section{Table 1. Case vignettes for the 6 cases in the survey}

\section{Case 1 (young and healthy)}

A 51-year-old female presents to you with a 2.9-cm right upper pole, anterior, renal mass with Nephrometry Score 4a (range 4-12), incidentally detected on an abdominal computed tomography (CT) scan. A biopsy confirmed renal cell carcinoma, Fuhrman grade 2. Staging tests reveal no evidence of metastases and the patient has a normal left kidney, with a pre-treatment eGFR of $96 \mathrm{~mL} / \mathrm{min} / 1.73 \mathrm{~m}{ }^{2}$. The patient's past medical history is significant for hypothyroidism.

\section{Case 2 (young with comorbid disease)}

A 52-year-old male presents to you with a 3.0-cm left upper pole, anterior, renal mass with Nephrometry Score 4a (range 4-12), incidentally detected on an abdominal CT scan. A biopsy confirmed renal cell carcinoma, Fuhrman grade 2. Staging tests reveal no evidence of metastases and the patient has a normal right kidney, with a pre-treatment eGFR of $70 \mathrm{~mL} / \mathrm{min} / 1.73 \mathrm{~m}^{2}$. The patient's past medical history is significant for hypertension, diabetes (non-insulin dependent) and gastroesophageal reflux disease.

\section{Case 3 (older and healthy)}

A 71-year-old female presents to you with a 2.8-cm left upper pole, anterior, renal mass with Nephrometry Score 4a (range 4-12), incidentally identified by ultrasound. A biopsy confirmed renal cell carcinoma, Fuhrman grade 2. Staging tests reveal no metastases and the patient has a normal right kidney, with a pre-treatment eGFR of $70 \mathrm{~mL} / \mathrm{min} / 1.73 \mathrm{~m}^{2}$. The patient's past medical history is significant for gallstones and remote history of appendectomy and stress incontinence surgery.

\section{Case 4 (older with comorbid disease)}

A 70-year-old male presents to you with a 2.9-cm right upper pole, anterior, renal mass with Nephrometry Score 4a (range 4-12), incidentally found on abdominal CT scan. A biopsy confirmed renal cell carcinoma, Fuhrman grade 2. Staging tests reveal no metastases and the patient has a normal left kidney, with a pre-treatment eGFR of $57 \mathrm{~mL} / \mathrm{min} / 1.73 \mathrm{~m}^{2}$. The patient's past medical history is significant for hypertension (well-controlled), diabetes (non-insulin dependent), migraines, and remote history of TURP for BPH.

\section{Case 5 (elderly and healthy)}

A 79-year-old male presents to you with a 3.1-cm right upper pole, anterior, renal mass with Nephrometry Score 4a (range 4-12), incidentally found on ultrasonography. A biopsy confirmed renal cell carcinoma, Fuhrman grade 2. Staging tests reveal no metastases and the patient has a normal left kidney, with a pre-treatment eGFR of $73 \mathrm{~mL} / \mathrm{min} / 1.73 \mathrm{~m}^{2}$. The patient's past medical history is significant for $\mathrm{BPH}$ and remote appendectomy.

\section{Case 6 (elderly with significant comorbid disease)}

A 80-year-old male presents to you with a 3.0-cm right upper pole, anterior, renal mass with Nephrometry Score 4a (range 4-12), incidentally found on ultrasonography. A biopsy confirmed renal cell carcinoma, Fuhrman grade 2. Staging tests reveal no metastases and the patient has a normal left kidney, with a pre-treatment eGFR of $58 \mathrm{~mL} / \mathrm{min} / 1.73 \mathrm{~m}^{2}$. The patient's medical history is significant for bilateral hip replacements, osteoarthritis, hypertension, renal stones, and COPD. 
Factors affecting treatment decisions in pT1a renal tumours

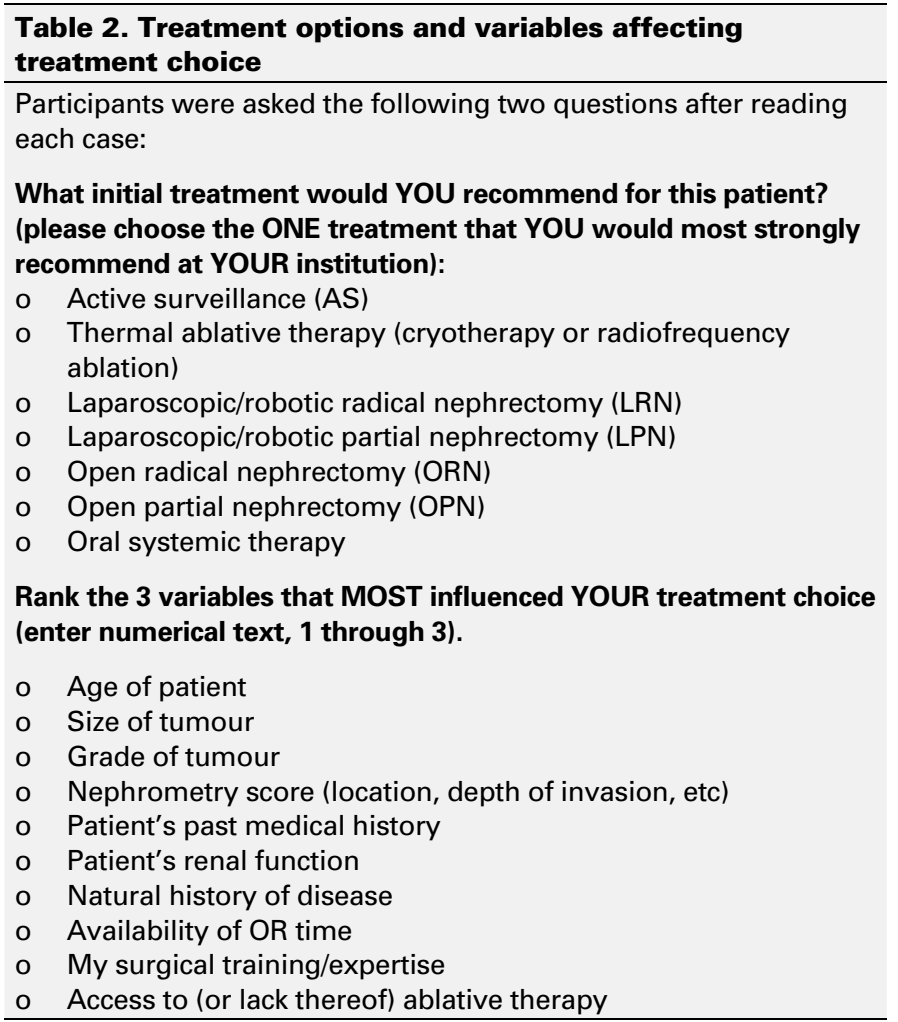

patients "often" or "almost daily;" only 5\% reported seeing them "rarely" (Table 3).

\section{Treatment choices}

With increasing age and comorbidity, AS and thermal ablative therapies were more often selected as the recommended treatment option; $7 \%, 8 \%, 33 \%, 41 \%, 60 \%, 81 \%$ for index patients $\mathrm{C} 1$ to $\mathrm{C} 6$, respectively. Overall, NSS (particularly $\mathrm{PN}$ ) was chosen by most respondents for $\mathrm{C} 1$ and $\mathrm{C} 2$, while few respondents selected surgical management ( $\mathrm{RN}$ or $\mathrm{PN})$ for C5 and C6 (Fig. 1).

When surgery was selected, an open surgical approach was more common for $\mathrm{C} 5$ and $\mathrm{C} 6$ as compared to $\mathrm{C} 1$ to C2 $(p<0.05)$, where a minimally invasive surgical (MIS) approach was preferred (Fig. 2).

\section{Surgeon characteristics}

Older age $(>65)$ was weakly correlated with a non-academic practice $(p<0.001)$, a personal history of cancer $(p<0.001)$, and the use of an open surgical approach $(p<0.013$ for all 6 cases). Similarly, academic urologists were more likely to be young $(<65, p<0.001)$, have completed a clinical fellowship $(p<0.001)$, see more RCC patients $(p<0.001)$, and recommend MIS options for surgery $(p<0.01$ for all 6 cases) (Table 4).

\begin{tabular}{|c|c|}
\hline Characteristic & No. (\%) \\
\hline \multicolumn{2}{|l|}{ Age } \\
\hline$<35$ & $9(8.2)$ \\
\hline $35-44$ & $47(42.7)$ \\
\hline $45-54$ & $26(23.6)$ \\
\hline $55-64$ & $8(7.3)$ \\
\hline $65-74$ & $17(15.5)$ \\
\hline$\geq 75$ & $3(2.7)$ \\
\hline \multicolumn{2}{|l|}{ Gender } \\
\hline Male & $99(90.0)$ \\
\hline Female & $11(10.0)$ \\
\hline \multicolumn{2}{|l|}{ Current practice location } \\
\hline British Columbia & $17(15.5)$ \\
\hline Alberta & 17 (15.5) \\
\hline Saskatchewan & $5(4.5)$ \\
\hline Manitoba & $5(4.5)$ \\
\hline Ontario & $50(45.5)$ \\
\hline Quebec & $11(10.0)$ \\
\hline Newfoundland and Labrador & $3(2.7)$ \\
\hline New Brunswick & $2(1.8)$ \\
\hline \multicolumn{2}{|l|}{ Academic practice } \\
\hline Yes & 49 (44.5) \\
\hline No & $61(55.5)$ \\
\hline \multicolumn{2}{|l|}{ Fellowship training } \\
\hline Any Fellowship & $65(59.1)$ \\
\hline Oncologic Fellowship & $23(20.9)$ \\
\hline No Fellowship Training & 45 (40.9) \\
\hline \multicolumn{2}{|c|}{$\begin{array}{l}\text { Participation in multidisciplinary "tumour board" } \\
\text { rounds }\end{array}$} \\
\hline Yes & $81(75.0)$ \\
\hline $\begin{array}{l}\text { Yes } \\
\text { No }\end{array}$ & $27(25.0)$ \\
\hline \multicolumn{2}{|c|}{ Frequency of renal cancer patients } \\
\hline Almost Daily & $21(19.4)$ \\
\hline Often & $47(43.5)$ \\
\hline Occasionally & $35(32.4)$ \\
\hline Rarely & $5(4.6)$ \\
\hline \multicolumn{2}{|l|}{ Personal hereditary of cancer } \\
\hline Yes & $7(6.4)$ \\
\hline No & $103(93.6)$ \\
\hline \multicolumn{2}{|c|}{ First degree relative died of cancer } \\
\hline Yes & $18(16.4)$ \\
\hline No & $92(83.6)$ \\
\hline
\end{tabular}

Recommending surgery (RN or PN) for both $\mathrm{C} 5$ and C6 (elderly patients) correlated with surgeon age $(>65)$ $(p<0.001)$, no oncologic fellowship training $(p=0.021)$, a non-academic practice $(p=0.003)$, a personal history of cancer $(p=0.038)$ and a family history of cancer death in the last 10 years $(p=0.022)$ (Table 5$)$. On multivariable analysis, only age $>65(p=0.043)$ and the lack of oncology fellowship training $(p=0.039)$ correlated with surgical management for both patients $\mathrm{C} 5$ and $\mathrm{C} 6$.

\section{Variables influencing treatment decisions}

For cases $\mathrm{C} 5$ and $\mathrm{C} 6$, age was the most commonly ranked influential variable among those who did not choose sur- 


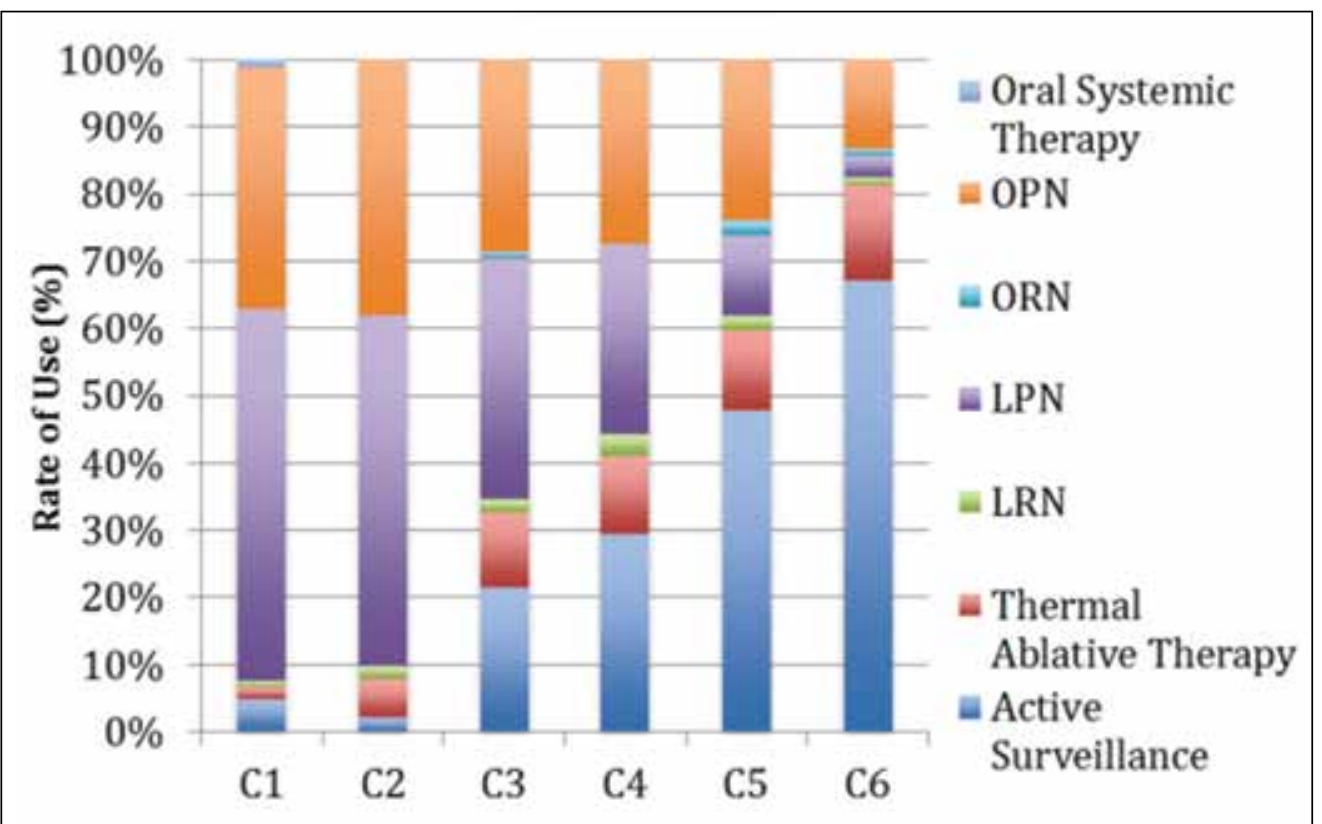

Fig. 1. Treatment choice by index case

gical treatment $(66 \%$ and $74 \%$, respectively) and among respondents $<65$ years of age $(72 \%$ and $75 \%$, respectively).

Conversely, age was not one of the top 3 influential variables ranked by respondents $>65$ years of age and those that did recommend surgical treatment for $\mathrm{C} 5$ and $\mathrm{C} 6$; personal training/experience was the most commonly ranked influential variable by respondents recommending surgery for both C5 and C6 (59\% and 65\%, respectively) (Table 6). stood by the patient.

\section{Discussion}

Contemporary management options for patients with RCC have dramatically increased, perhaps due to increasing concerns regarding surgicallyinduced renal dysfunction, ${ }^{6,23}$ but also as a result of the introduction of innovative surgical technologies. In fact, there is no longer a single gold standard option for RCC (i.e., open radical nephrectomy), ${ }^{24}$ particularly for pT1a tumours.

Ultimately, when deciding on a "best" option, urologists attempt to balance the competing risks associated with different treatment options, taking into consideration not only disease-specific factors but patient-related factors as well. ${ }^{25-26}$ Surgeon-specific factors may also have a significant impact on this decision-making process, though such variables are often not explicitly under-

This online survey study of Canadian urologists provides further evidence of an emerging paradigm shift away from the traditional gold standard RN for RCC. As comparable oncologic safety evidence emerges, ${ }^{9-10}$ and training and expertise in advanced MIS techniques permeate the specialty, many urologists have embraced elective NSS as a safe and efficacious option. To further illustrate this point, $92 \%$ of respondents chose PN as the treatment of choice for patient $\mathrm{C} 1$, a healthy 51-yearold with a normal contralateral kidney and good overall renal function. In addition, of the respondents who opted for surgery (RN or $\mathrm{PN}$ ) for $\mathrm{C} 1,61 \%$ reported that they would use a MIS approach (laparoscopic or robotic).

With emerging evidence regarding its safety, the role of AS for small RCCs has also increased. ${ }^{27-33}$ In this study, AS was recommended by $21 \%$ of urologists for C3, 30\% for C4, $48 \%$ for $\mathrm{C} 5$, and $67 \%$ for C6.
Fig. 2. Minimally invasive versus open surgery in cases being treated surgically. MIS: minimally invasive surgery; Open: open surgery. ${ }^{*}$ statistically significant difference compared to $\mathrm{C} 1$ and $\mathrm{C} 2(\mathrm{p}<0.05)$. 


\begin{tabular}{lcc}
\hline \multicolumn{2}{l}{ Table 4. Significant correlations between demographic } \\
characteristics & r / $\rho$ & p value \\
\hline Correlation & & \\
\hline Age (>65 years): & 0.342 & $<0.01$ \\
Non-academic practice & -0.316 & $<0.01$ \\
Working with trainees & -0.349 & $<0.01$ \\
Clinical fellowship & -0.269 & $<0.01$ \\
Larger catchment area of practice & 0.442 & $<0.01$ \\
Personal history of cancer & & \\
Academic urologists: & -0.342 & $<0.01$ \\
Age >65 years & 0.834 & $<0.01$ \\
Working with trainees & 0.560 & $<0.01$ \\
Clinical fellowship & 0.456 & $<0.01$ \\
Larger catchment area of practice & 0.365 & $<0.01$ \\
More likely to see RCC patients & & \\
Less likely to have first degree relative who & 0.199 & 0.04 \\
died of cancer & & \\
Having completed an Oncology Fellowship: & -0.439 & $<0.01$ \\
Non-academic practice & 0.364 & $<0.01$ \\
\hline More likely to see RCC patients & & \\
\hline RCC: renal cell carcinoma. & &
\end{tabular}

Interestingly, $5 \%$ of urologists offered AS to patient $\mathrm{C} 1$. Thermal ablation was relatively uncommon, with at most only $14 \%$ (C6) of urologists recommending this option.

Index patients $\mathrm{C} 5$ and $\mathrm{C} 6$ were about 80 years old, close to the current average life expectancy in Canada. ${ }^{34}$ Particularly for patient C6 (multiple medical comorbidities), either AS or thermal ablation, could be reasonable, safe options. Conversely, for the same patient, it could be argued that PN and RN are somewhat "aggressive" management options given the high surgical risk. We examined the treatment options for $\mathrm{C} 5$ and $\mathrm{C} 6$, with the assumption that surgical management (RN and $\mathrm{PN}$ ) was considered an "aggressive" option.

We found that only $34 \%$ and $16 \%$ of urologists would recommend such an "aggressive" treatment option for C5 and C6, respectively. Interestingly, urologists were more likely to offer such "aggressive" options if they themselves were $>65$ years of age, practicing in non-academic settings, without oncology fellowship training, and with either a personal history of cancer or whom had a first-degree relative die of cancer within the past 10 years. Among those recommending $\mathrm{RN}$ or $\mathrm{PN}$, respondents did not consider patient age in their decision-making process; age was not one of the 3 most important considerations in selecting the optimal management option.

From the methodology of this survey, we are unable to discern the exact reasons why older urologists and those with either a personal or family history of cancer would be more likely to select a more aggressive treatment option for elderly patients with SRMs. However, among the respondents in this study, urologists $>65$ years of age were less likely to have completed an oncology fellowship and were more commonly from non-academic practices, perhaps indicating a knowledge translation issue.

Also, though not well-studied, ageism in health care is an all too prevalent phenomenon. ${ }^{35-36}$ With increasing life expectancies and innovative MIS treatment options, age alone should not be an exclusionary criterion for treating patients with RCC. Among respondents, older urologists

Table 5. Variables affecting treatment decisions in Case 5 and Case 6

\begin{tabular}{|c|c|c|}
\hline Surgeon characteristic (no. respondents) & Case no.: Top 3 variables & No. respondents (\%) \\
\hline $\begin{array}{l}\text { Recommended aggressive treatment (surgery) } \\
\text { for C5 \& C6 }(n=17)\end{array}$ & $\begin{array}{c}\text { Case 5: Personal training/experience } \\
\text { Medical history } \\
\text { Patient's renal function } \\
\text { Case 6: Personal training/experience } \\
\text { Patient's renal function } \\
\text { Tumour size }\end{array}$ & $\begin{array}{l}10(59 \%) \\
8(47 \%) \\
8(47 \%) \\
11(65 \%) \\
10(59 \%) \\
7(41 \%)\end{array}$ \\
\hline $\begin{array}{l}\text { Did NOT recommend aggressive treatment } \\
\text { (surgery) for both C5 \& C6 }(n=93)\end{array}$ & $\begin{array}{l}\text { Case 5: Age } \\
\text { Tumour size } \\
\text { Natural history } \\
\text { Case 6: Age } \\
\text { Medical history } \\
\text { Tumour size }\end{array}$ & $\begin{array}{l}61(66 \%) \\
58(62 \%) \\
32(34 \%) \\
69(74 \%) \\
46(49 \%) \\
42(45 \%)\end{array}$ \\
\hline Age $>65$ years $(n=21)$ & $\begin{array}{l}\text { Case 5: Medical history } \\
\text { Patient's renal function } \\
\text { Natural history } \\
\text { Case 6: Patient's renal function } \\
\text { Medical history } \\
\text { Natural history }\end{array}$ & $\begin{array}{l}12(57 \%) \\
12(57 \%) \\
7(33 \%) \\
13(62 \%) \\
11(52 \%) \\
10(48 \%)\end{array}$ \\
\hline Age $<65$ years $(n=89)$ & $\begin{array}{l}\text { Case 5: Age } \\
\text { Tumour size } \\
\text { Natural History } \\
\text { Case 6: Age } \\
\text { Tumour size } \\
\text { Medical history }\end{array}$ & $\begin{array}{l}64(74 \%) \\
60(67 \%) \\
29(33 \%) \\
67(75 \%) \\
47(53 \%) \\
40(45 \%)\end{array}$ \\
\hline
\end{tabular}


Millman et al.

\begin{tabular}{|c|c|c|}
\hline Surgeon characteristic (no. respondents) & Case no.: Top 3 variables & No. respondents (\%) \\
\hline $\begin{array}{l}\text { Recommended aggressive treatment (surgery) } \\
\text { for C5 \& C6 }(n=17)\end{array}$ & $\begin{array}{c}\text { Case 5: Personal training/experience } \\
\text { Medical history } \\
\text { Patient's renal function } \\
\text { Case 6: Personal training/experience } \\
\text { Patient's renal function } \\
\text { Tumour size }\end{array}$ & $\begin{array}{l}10(59 \%) \\
8(47 \%) \\
8(47 \%) \\
11(65 \%) \\
10(59 \%) \\
7(41 \%)\end{array}$ \\
\hline $\begin{array}{l}\text { Did NOT recommend aggressive treatment } \\
\text { (surgery) for both C5 \& C6 ( }=93)\end{array}$ & $\begin{array}{c}\text { Case 5: Age } \\
\text { Tumour size } \\
\text { Natural history } \\
\text { Case 6: Age } \\
\text { Medical history } \\
\text { Tumour size }\end{array}$ & $\begin{array}{l}61(66 \%) \\
58(62 \%) \\
32(34 \%) \\
69(74 \%) \\
46(49 \%) \\
42(45 \%)\end{array}$ \\
\hline Age $>65$ years $(n=21)$ & $\begin{array}{l}\text { Case 5: Medical history } \\
\text { Patient's renal function } \\
\text { Natural history } \\
\text { Case 6: Patient's renal function } \\
\text { Medical history } \\
\text { Natural history }\end{array}$ & $\begin{array}{l}12(57 \%) \\
12(57 \%) \\
7(33 \%) \\
13(62 \%) \\
11(52 \%) \\
10(48 \%)\end{array}$ \\
\hline Age $<65$ years $(n=89)$ & $\begin{array}{l}\text { Case 5: Age } \\
\text { Tumour size } \\
\text { Natural History } \\
\text { Case 6: Age } \\
\text { Tumour size } \\
\text { Medical history }\end{array}$ & $\begin{array}{l}64(74 \%) \\
60(67 \%) \\
29(33 \%) \\
67(75 \%) \\
47(53 \%) \\
40(45 \%)\end{array}$ \\
\hline
\end{tabular}

were more likely to offer "aggressive" treatment options to elderly patients (C5 and C6). One could hypothesize that either this is evidence that younger surgeons display an affinity to ageist practices or, conversely, that older surgeons are more apt to offer "aggressive" treatment options to their own generational cohort. Interestingly, for index patients C3 and C4 (both about 70), urologist age did not correlate with a decision to offer surgical management ( $p=0.538)$.

Our survey demonstrates that with increasing patient age, comorbidities, and renal dysfunction, Canadian urologists are likely to offer AS or NSS to patients with pT1a RCC. In addition, the reported utilization of MIS techniques for the management of T1a RCC in Canada seems to be increasing compared to recent population-based observational data. ${ }^{37}$ Both age of surgeon and practice setting seem to play a role in determining not only whether MIS techniques are utilized, but whether surgical options are offered in select index patients.

A similar study of American Urological Association (AUA) members in 2009 also found that various surgeon-factors (surgeon age, practice location, higher renal case volume) significantly influenced the use of PN. ${ }^{11}$ While this study also examined surgeon-specific variables, the authors focused more on tumour characteristics within a set of healthy index patients. In a related publication, however, the same authors presented the results of the full survey that included index cases of variable ages, renal function, and comorbidities. ${ }^{38}$ Interestingly, although there were slight differences between index patients in this study and ours (e.g., $3 \mathrm{~cm}$ vs. $2-4 \mathrm{~cm}$ ), similar management patterns were seen for patients with comparable age, renal function, and comorbidity. Notable differences among our Canadian respondents included an increased use of AS among healthier patients, an overall lower rate of RN among comparable patients, and a lower reported utilization of thermal ablation in Canada. These differences might be explained by the litigious nature of American healthcare system, the time interval between survey studies, and the prohibitive cost of ablation therapy in Canada.

There are several limitations to our study. First, as with many physician survey studies, our response rate was low $(18 \%)$. Unfortunately, we were unable to direct our email blast to only the practicing, adult urologists in Canada. As such, the 110 respondents may in fact represent a larger proportion of the valid audience. Secondly, almost half $(45 \%)$ of respondents were practicing in an academic setting, which represents an oversampling of this subgroup of urologists. Also, while statistically significant, many of our correlations were weak (i.e., correlation coefficient $<0.5$ ). As with all survey studies, the results may have had inherent social desirability biases as well. Finally, as this study was solely solicited via email, there may be deficiencies in its completeness; we may not have reached all urologists.

\section{Conclusion}

There are various disease-specific and patient-related factors that affect the decision-making process when manag- 
ing patients with pT1a RCC in Canada. Our online survey study of CUA member urologists demonstrates that surgeonspecific factors may also significantly influence treatment decisions and should be considered when offering patients treatment options.

Competing interests: Dr. Millman, Dr. Pace, Dr. Ordon and Dr. Lee all declare no competing financial or personal interests.

This paper has been peer-reviewed.

\section{References}

1. Luciani LG, Cestari R, Tallarigo C. Incidental renal cell carcinoma-age and stage characterization and clinical implications: study of 1092 patients (1982-1997). Urology 2000;56:58-62. http://dx.doi. org/10.1016/50090-4295(00)00534-3

2. Kutikov A, Smaldone MC, Egleston BL, et al. Anatomic features of enhancing renal masses predict malignant and high-grade pathology: A preoperative nomogram using the RENAL Nephrometry Score. Eur Urol 2011;60:241-8. http://dx.doi.org/10.1016/i.eururo.2011.03.029

3. Duchene DA, Lotan Y, Cadeddu JA, et al. Histopathology of surgically managed renal tumors: Analysis of a contemporary series. Urology 2003;62:827-30. http://dx.doi.org/10.1016/S0090-4295(03)00658-7

4. Frank I, Blute ML, Cheville JC, et al. Solid renal tumors: An analysis of pathological features related to tumor size. J Urol 2003;170:2217-20. http://dx.doi.org/10.1097/01.ju.0000095475.12515.5e

5. Sun $M$, Abdollah $F$, Binachi $M$, et al. Treatment managment of small renal masses in the 21 st century: A paradigm shift. Ann Surg Oncol 2012;19:2380-7. http://dx.doi.org/10.1245/s10434-012-2247-0

6. Go AS, Chertow GM, Fan D, et al. Chronic kidney disease and the risks of death, cardiovascular events, and hospitalization. N Engl J Med 2004;351:1296-305. Erratum in: N Engl J Med 2008;18:4. http:// dx.doi.org/10.1056/NEJMon041031

7. Klinghoffer Z, Tarride J, Novara G, et al. Cost-utility analysis of radical nephrectomy versus partial nephrectomy in the management of small renal masses: Adjusting for the burden of ensuing chronic kidney disease. Can Urol Assoc J 2013;7:108-13.

8. Crepel $M$, Jeldres $C$, Sun $M$, et al. A population-based comparison of cancer- control rates between radical and partial nephrectomy for TIA renal cell carcinoma. Urology 2010;76:883-8. http://dx.doi. org/10.1016/i.urology.2009.08.028

9. Van Poppel H, Da Pozzo L, Albrecht W, et al. A prospective, randomised EORTC intergroup phase 3 study comparing the oncologic outcome of elective nephron-sparing surgery and radical nephrectomy for low-stage renal cell carcinoma. Eur Urol 2007;51:1606-15. http://dx.doi.org/10.1016/j.eururo.2006.11.013

10. Touijer K, Jacqmin D, Kavoussi LR, et al. The expanding role of partial nephrectomy: A critical analysis of indications, results, and complications. Eur Urol 2010;57:214-22. http://dx.doi.org/10.1016/i. eururo.2009.10.019

11. Weight CJ, Crispen PL, Breau RH, et al. Practice-setting and surgeon characteristics heavily influence the decision to perform partial nephrectomy among American Urologic Association surgeons. BJU Int 2013;111:731-8. http://dx.doi.org/10.1111/i.1464-410X.2012.11112.x

12. Abouassaly R, Finelli A, Tomlinson $G A$, et al. How often are patients with diabetes or hypertension being treated with partial nephrectomy for renal cell carcinoma? A population-based analysis. BJU Int 2011;108:1806-12. htrp://dx.doi.org/10.1111/i.1464-410X.2011.10254.x

13. Buethe DD, Spiess PE. Current management considerations for the incidentally detected small renal mass. Cancer Control 2013;20:211-21.

14. Rendon RA. Active surveillance as the preferred management option for small renal masses. Can Urol Assoc J 2010;4:136-8. http://dx.doi.org/10.5489/cuaj.10038

15. Kapoor A, Touma NJ, Dib RE. Review of the efficacy and safety of cryoablation for the treatment of small renal masses. Can Urol Assoc J 2013;7:E38-44.

16. Zhang ZY, Tang $Q$, Li XS, Zhang $Q$, et al. Clinical analysis of the PADUA and the RENAL scoring systems for renal neoplasms: A retrospective study of 245 patients undergoing laparoscopic partial nephrectomy. Int J Urol 2014;21:40-4. http://dx.doi.org/10.1111/iiu.12192. Epub 2013 May 15.

17. Hew MN, Baseskioglu B, Barwari K, et al. Critical appraisal of the PADUA classification and assessment of the R.E.N.A.L. Nephrometry Score in patients undergoing partial nephrectomy. J Urol 2011;186:42-6. http://dx.doi.org/10.1016/i.juro.2011.03.020
18. Kutikov A, Uzzo RG. The R.E.N.A.L. Nephrometry Score: A comprehensive standardized system for quantitating renal tumor size, location and depth. J Urol 2009;182:844-53. http://dx.doi.org/10.1016/i. juro.2009.05.035

19. Schmit GD, Thompson RH, Kurup AN, et al. Usefulness of R.E.N.A.L. Nephrometry scoring system for predicting outcomes and complications of percutaneous ablation of 751 renal tumors. J Urol 2013;189:30-5. http://dx.doi.org/10.1016/i.juro.2012.08.180

20. Sisul DM, Liss MA, Palazzi KL, et al. RENAL Nephrometry Score is associated with complications after renal cryoablation: A multicenter analysis. Urology 2013;81:775-80. http://dx.doi.org/10.1016/i. urology.2012.11.037

21. Ficarra V, Novara G, Secco $S$, et al. Preoperative aspects and dimensions used for an anatomical (PADUA) classification of renal tumours in patients who are candidates for nephron-sparing surgery. Eur Urol 2009:56:786-93. http://dx.doi.org/10.1016/i.eururo.2009.07.040

22. Waldert $M$, Waalkes $S$, Klatte $T$, et al. External validation of the preoperative anatomical classication for prediction of complications related to nephron-sparing surgery. World J Urol 2010;28:531-5. http:// dx.doi.org/10.1007/s00345-010-0577-8

23. Huang WC, Levey AS, Serio AM, et al. Chronic kidney disease after nephrectomy in patients with renal cortical tumours: A retrospective cohort study. Lancet Oncol 2006;7:735-40. http://dx.doi.org/10.1016/ S1470-2045(06) 70803-8

24. Robson CJ, Churchill BM, Anderson W. The results of radical nephrectomy for renal cell carcinoma. 1969. J Urology. 2002;167:873-5; discussion 876-7. htrp://dx.doi.org/10.1016/50022-5347(02)80286-5. Reprinted from I Urol 1969;101:297-301.

25. Zisman A, Patard JJ, Raz 0, et al. Sex, age, and surgeon decision on nephron-sparing surgery are independent predictors of renal masses with benign histologic findings—A multicenter survey. Urology 2010;76:541-6. hittp://dx.doi.org/10.1016/i.urology.2010.01.089

26. Yang $G$, Villalta JD, Meng MV, et al. Evolving practice patterns for the management of small renal masses in the USA. BJU Int 2012;110:1156-61. http://dx.doi.org/10.1111/i.1464-410X.2012.10969.x

27. Lane $B R$, Tobert $C M$, Riedinger $C B$. Growth kinetics and active surveillance for small renal masses. Curr Opin Urol 2012;22:353-9. http://dx.doi.org/10.1097/MOU.0b013e328355ecdf

28. Patel $\mathrm{N}$, Cranston D, Akhtar MZ, et al. Active surveillance of small renal masses offers short-term oncological efficacy equivalent to radical and partial nephrectomy. BJU Int 2012;110:1270-5. http://dx.doi. org/10.1111/j.1464-410X.2012.11130.x

29. Smaldone MC, Kutikov A, Egleston BL, et al. Small renal masses progressing to metastases under active surveillance. Cancer 2012;118:997-1006. http://dx.doi.org/10.1002/cncr.26369

30. Jewett MA, Mattar K, Basiuk J, et al. Active surveillance of small renal masses: Progression patterns of early stage kidney cancer. Eur Urol 201 1;60:39-44. http://dx.doi.org/10.1016/j.eururo.2011.03.030

31. Crispen PL, Viterbo R, Boorijian SA, et al. Natural history, growth kinetics, and outcomes of untreated clinically localized renal tumors under active surveillance. Cancer 2009;115:2844-52. http://dx.doi. org/10.1002/cncr.24338

32. Beisland C, Hielle $K M$, Reisaeter $L A$, et al. Observation should be considered as an alternative in management of renal masses in older and comorbid patients. Eur Urol 2009;55:1419-27. http://dx.doi. org/10.1016/i.eururo.2008.12.031

33. Crispen PL, Wong YN, Greenberg RE, et al. Predicting growth of solid renal masses under active surveillance. Urol Oncol 2008;26:555-9. http://dx.doi.org/10.1016/i.urolonc.2008.03.010

34. Life expectancy at birth, by sex, by province. Statistics Canada. http://www.statcan.gc.ca/tablestableaux/sum-som/101/cst01/health26-eng.htm. Accessed May 2, 2014.

35. Peake MD, Thompson S, Lowe D, et al. on behalf of the Participating Centres. Ageism in the management of lung cancer. Age Ageing 2003;32:171-7. http://dx.doi.org/10.1093/ageing/32.2.171

36. Madan AK, Aliabadi-Wahle $S$, Beech DJ. Ageism in medical students' treatment recommendations: the example of breast-conserving procedures. Acad Med 2001;76:282-4. http://dx.doi. org/10.1097/00001888-200103000-00019

37. Abouassaly R, Finelli A, Tomlinson GA, et al. Volume-outcome relationships in the treatment of renal tumors. J Urol 2012;187:1984-8. http://dx.doi.org/10.1016/i.juro.2012.01.076

38. Breau RH, Crispen PL, Jenkins SM, et al. Blute ML, Leibovich BC. Treatment of patients with small renal masses: A survey of the American Urological Association. J Urol 201 1;185:407-13. http://dx.doi. org/10.1016/i.juro.2010.09.092

Correspondence: Dr. Jason Young Lee, Division of Urology, Department of Surgery, St. Michael's Hospital, University of Toronto, Toronto, ON; leejasosmh@gmail.com 